\title{
Targeting Tumor Associated Antigens For The Development of Hepatocellular Carcinoma Treatment.
}

Sthiti Porna Dutta ( $\square$ sthitidutta7@gmail.com )

Royal Global University https://orcid.org/0000-0002-8213-3063

Anis Alam

North-Eastern Hill University

\section{Research Article}

Keywords: TAA, Liver cancer, liver mitochondria, DBN

Posted Date: January 3rd, 2022

DOI: https://doi.org/10.21203/rs.3.rs-1158826/v1

License: (c) (1) This work is licensed under a Creative Commons Attribution 4.0 International License.

Read Full License 


\section{Abstract}

DBN possess the ability to induce bladder tumor as well as in the liver, and oesophagus when it is administered in the body.Exposure to DBN can happen by different modes such as by ingestion,inhalation as well through dermal contact.In the present investigation an attempt has been done to identify, isolate as well to purify he TAA from the liver mitochondria of the mice which was exposed to DBN. It was found that mitochondrial membrane surface protein of DBN-exposed animals exhibited differential expression when compared with the control animals. A low molecular weight ( 14 $\mathrm{kDa}$ ) protein was found to be over expressed on liver mitochondrial membrane upon DBN exposure in mice as compared with the normal control and identified as TAA, showing the sign that some of the proteins could be used as TAA for further study.

These identification and molecular characterization of TAAs will provide the basis for the development of cancer vaccines targeting TAAs.

\section{Introduction}

N-Nitrosodibutylamine is a class of nitrosamine reasonably anticipated to be a human carcinogen based on sufficient evidence of carcinogenicity in experimental animals and has a half-life of 2.8 days (computer estimated) (Matsuhashi et al., 1996). DBN possess the ability to induce bladder tumor as well as in the liver, and oesophagus when it is administered in the body. It causes cancer by different modes of exposure, such as ingestion, inhalation, and dermal contact such as skin painting.

Based upon experiments, a mechanism was proposed for the metabolic pathways of $\mathrm{N}$,Nitrosodibutylamine i.e. metabolic bioactivation pathway to a highly reactive ultimate carcinogen that can add an alkyl group to the 06 and N7 of guanine (Bradfield, 2009).

The role of mitochondria in disease has been expanded beyond the respiratory chain, as defects in additional mitochondrial functions and behaviours have been linked to cancer, metabolic disorders, and neurodegenerative diseases, such as Alzheimer's, Parkinson's and Huntington's disease (Nunnari et al., 2012).

As mitochondrial plays a dominant role in controlling various parameters so changes in these parameters can effect on biosynthetic pathways, cellular signal transduction pathways, transcription factors and chromatin structure to shift the cell from a quiescent, differentiated state to an actively proliferating one. Analysis of the consequences of mitochondrial gene mutations is providing broad new insights into the importance and complexity of mitochondrial alterations in cancer, although mutations in the mIDNA in cancer cells have been recognized for more than two decades (Horton et al., 1996). Interest in the role of mitochondrial alterations in cancer came to general attention with the discovery of mitochondrial tricarboxylic acid (TCA) cycle gene mutations in cancer cells. 
One of the modest approaches to improve systemic cancer therapy is the specific active immunotherapy with preparations containing purified TAA instead of the whole tumor cell (Minev et al., 1999). The TAA which are present mainly in the tumor cells includes growth factors, growth factors receptors as well as oncogene-encoded protein. Oncofetal tumor antigens are found not only in the cancerous cell but also seen on normal fetal cells (Urban et al., 1992). The increase in the level of these can be recognized by the immune system and immune system mounts an immune response and destroys these cells without damaging any normal cells (Kuby, 1997).

The identification and molecular characterization of TAAs provided the basis for the development of cancer vaccines targeting TAAs (Greten et al., 1999).

\section{Materials And Methods}

\section{EXPERIMENTAL ANIMALS}

Swiss albino mice (BALB/c) 10-15 numbers in each group, bred by random breeding at the animal house of the department were kept on basal diet ad libitum in plastic cages at the temperature-controlled animal room $\left(21 \pm 2^{\circ} \mathrm{C}\right)$ with 12 hours light and dark cycle. At the start of the experiment, the mice were 6-8 weeks old weighing around 22-25 gm in weight. Sex chosen for the experiment was female.

\section{CANCER INDUCTION}

A weekly dose of $10 \mathrm{mg}$ per $\mathrm{kg}$ body weight of (N-Nitrosodibutylamine) DBN in 5\% ethanol was administered intravenously in healthy female mice of 6-8 weeks old weighing around $22-25 \mathrm{gm}$ for a period of 16 weeks and sacrificed at the end of treatment as required. Age-matched sham-treated mice served as control. All animal procedures were performed according to approved protocol and in accordance with recommendations for the proper use and the care of the laboratory animals. The induction of carcinogenesis was followed by monitoring various parameters such as GGT, AChE, GST, SGOT, and SGPT. Beside this histological examination was also done.

\section{MITOCHONDRIAL MEMBRANE PROTEIN ISOLATION}

\section{PROTEIN EXTRACTION}

The mitochondrial membrane protein was isolated from the liver mitochondria of the normal control mice and treated mice by method described by Frilabo, with slight modifications.

Requirements

- 25mM HEPES-KOH (pH 7.6 adjust with $\mathrm{KOH})$

- $1 \mathrm{mM}$ DTT

- 1MM PMSF

- $10 \%$ Glycerol 
- $0.5 \mathrm{mM}$ EDTA

- $5 \mathrm{mM} \mathrm{MgCl} 2$

- $0.5 \mathrm{M} \mathrm{KCl}$

- Lysis buffer: To make $250 \mathrm{ml}$ of lysis buffer the following are added:

- 25mM HEPES-KOH,1mM DTT,1mM PMSF,10\% glycerol,0.5mM EDTA and 5mM MgCl2 and mixed well.

- $0.5 \%$ Tween 20

Procedure

In brief, the isolated mitochondria were re-suspended in 1/3 the packed cell volume lysis buffer ( $25 \mathrm{mM}$ HEPES-KOH pH 7.6; 5 mM MgCl2; 0.5 mM EDTA; 10\% Glycerol; 1 mM DTT; 1 mM

PMSF). The suspension was put into a glass homogenizer and homogenize with a tight pestle. $0.5 \%$ Tween 20 and $1 \mathrm{M} \mathrm{KCl}$ were then added. The mixture was incubated on ice for 5 minutes. The homogenization is repeated 10 times and the final mitochondrial lysate was spun at $100,000 \mathrm{~g}$ in an ultracentrifuge (Thermo Scientific Sorvall EX Ultra 100 centrifuge) at $4^{\circ} \mathrm{C}$ for 60 minutes. The clear supernatant was carefully collected, avoiding the fluffy layer over the pellet, to yield the final protein fraction. The protein fractions were then stored in aliquots and stored at $-80^{\circ} \mathrm{C}$.

\section{IDENTIFICATION AND PURIFICATION OF THE TAA}

\section{SDS-PAGE ANALYSIS OF THE EXTRACT}

The mitochondrial protein extracts obtained from the control and treated mice were subjected to sodium dodecyl sulphate-polyacrylamide gel electrophoresis to resolve the proteins and identify the overexpressed proteins as TAA of our interest.

Requirements

- Acrylamide stock solution:29.2gm of acrylamide and $0.8 \mathrm{gm}$ of bisacrylamide were dissolved in a final volume of $100 \mathrm{ml}$ in distilled water.

- $1.5 \mathrm{M}$ Tris-HCl buffer(pH 8.8)

- $0.5 \mathrm{M}$ Tris-HCl buffer(pH6.8)

- $10 \%$ Ammonium persulphate

- $10 \%$ Sodium dodecyl sulphate

- 1X Electrode reservoir buffer: $0.025 \mathrm{M}$ Tris, $0.19 \mathrm{M}$ Glycine and $0.1 \%$ SDS adjusted to a pH of 8.3.

- 5X sample buffer: $5 \mathrm{ml}$ of $0.5 \mathrm{M}$ Tris- $\mathrm{HCl}$ buffer $\mathrm{pH} 6.8,5 \mathrm{gm}$ sucrose, $0.25 \mathrm{ml}$ mercapthoethanol, $1 \mathrm{ml}$ of $0.5 \%$ bromophenol blue made up to a final volume of $10 \mathrm{ml}$ with double distilled water.

- TEMED 
Acrylamide discontinuous gels (resolving gel 15\% and stacking gel 4\%) were prepared according to the procedure described by (Laemmeli, 1970). Briefly, a mixture of $2.35 \mathrm{ml}$ of distilled water,2.5ml of $1.5 \mathrm{M}$ Tris-

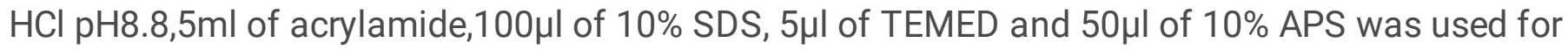
making the resolving gel. The solution was mixed gently and carefully poured between the glass plates assembled for the electrophoretic run and was left for polymerization. A space of $3 \mathrm{~cm}$ was left on the top of the gel for the casting of stacking gel. The stacking gel of $4 \%$ was made by mixing $6.1 \mathrm{ml}$ of distilled water, $2.5 \mathrm{ml}$ of $0.5 \mathrm{M}$ Tris- $\mathrm{HCl} \mathrm{pH} 6.8,1.33 \mathrm{ml}$ of acrylamide, $100 \mu \mathrm{l}$ of $105 \mathrm{SDS}, 10 \mu \mathrm{l}$ of TEMED and $50 \mu \mathrm{l}$ of $10 \%$ APS and poured over the polymerized resolving gel and the comb was inserted into it make wells for loading the samples. The comb was removed after polymerization of the gel to which protein sample is to be loaded. The whole setup was then transferred to the electrophoretic chamber, and reservoir buffer solution was poured slowly. $25 \mu$ l of the protein sample was mixed with $6.25 \mu$ l of sample buffer and heated in boiling water for about 3 mins. The sample was then loaded into wells. Molecular weight markers were also loaded onto the gel. The gel was run at a constant voltage of $200 \mathrm{~V}$ and a current of $60 \mathrm{~mA}$ for $45 \mathrm{mins}$. After completion of run gel was fixed in methanol/acetic acid, stained with coomassie brilliant blue R250 till protein bands are observed and destained with methanol/acetic acid for a few minutes.

\section{ION-EXCHANGE CHROMATOGRAPHY}

Ion exchange chromatography was employed to separate and identify the protein.

Ion-exchange Chromatography is a widely used technique for the separation of proteins based on Coulombic interaction. It has two types:

- Cation: for separating the positively charged proteins

- Anion: for separating negatively charged proteins.

To separate and purify the TAA, the crude mitochondrial protein extract was subjected to cation exchange chromatography.

Cation-exchange chromatography: The crude extract from both the normal and treated were run individually on CM- Sephadex C50.

Requirements

- CM-Sephadex C50.

- 50mM Phosphate buffer, pH 7: Buffer A.

- $100 \mathrm{mM} \mathrm{NaCl}$ in buffer A: Buffer B.

Procedure 
The concentration of the protein in the mitochondrial protein extract was estimated by the Bradford's method

(Bradford M.M., 1976). It was then dialyzed overnight against buffer $A$ at room temperature. The column was packed with the CM-Sephadex C50 matrix and was washed with buffer A. Unbound proteins were eluted out with the same buffer $A$. The proteins bound to exchanger were then eluted out from the column by applying a linear gradient of approximately $100 \mathrm{mM} \mathrm{NaCl}$ Buffer B. Fractions of $1.5 \mathrm{ml}$ were collected and the absorbance were read at $280 \mathrm{~nm}$.

\section{PURIFICATION OF TAA FROM SDS-PAGE GEL}

The unbound protein obtained from the cation-exchange chromatography column was subjected to preparative SDS- PAGE for the further purification.

Requirements

- Acrylamide stock solution: $29.2 \mathrm{gm}$ of acrylamide and $0.8 \mathrm{gm}$ of bis-acrylamide were dissolved in a final volume of $100 \mathrm{ml}$ in distilled water.

- $1.5 \mathrm{M}$ Tris-HCl buffer (pH 8.8)

- $0.5 \mathrm{M}$ Tris- $\mathrm{HCl}$ buffer(pH6.8)

- $10 \%$ Ammonium per sulphate

- $10 \%$ Sodium dodecyl sulphate

- 1X Electrode reservoir buffer: $0.025 \mathrm{M}$ Tris, $0.19 \mathrm{M}$ Glycine and $0.1 \%$ SDS adjusted to a pH of 8.3.

- 5X sample buffer: $5 \mathrm{ml}$ of $0.5 \mathrm{M}$ Tris- $\mathrm{HCl}$ buffer $\mathrm{pH} 6.8,5 \mathrm{gm}$ sucrose, $0.25 \mathrm{ml}$ mercapthoethanol, $1 \mathrm{ml}$ of $0.5 \%$ bromophenol blue made up to a final volume of $10 \mathrm{ml}$ with double distilled water.

- TEMED

Procedure

The fractions corresponding to peaks obtained from the cation exchange chromatography column was run on SDS- PAGE along with a crude extract. A longitudinal section of the gel corresponding to the crude extract lane was cut and stained. This was used as a reference to locate the exact position of the TAA in the rest of the gel. The portion of the gel corresponding to the TAA was cut off the unstained gel. It was cut into small pieces and homogenized in 3\% 1-butanol. The homogenate was centrifuged $8000 \mathrm{~g}$ for $30 \mathrm{~min}$ at $4^{\circ} \mathrm{C}$. The supernatant was collected and the pellet was resuspended in $3 \% 1$-butanol and centrifuged. The supernatant collected was pooled, dialyzed against distilled water overnight and lyophilized. It was then run on an SDS-PAGE gel.

\section{Result}




\section{SDS-PAGE ANALYSIS OF THE ISOLATED MITOCHONDRIAL MEMBRANE PROTEIN AND IDENTIFICATION OF TAA}

After 16 weeks of treatment, marker enzyme test clearly indicated the pathogenesis of liver cancer. Histological examination showed that cells are in rapid state of division and support the progression of cancer induction. After looking at the results of marker enzymes, liver function test and histological examination of the liver tissues it was confirmed that DBN $(10 \mathrm{mg} / \mathrm{kg}$ body weight) at a weekly interval for 16 weeks induces liver cancer. After successful induction of liver cancer by DBN our main target of interest was to see whether DBN affects the liver mitochondria and its membrane surface protein or not.

Total protein concentration was estimated in isolated mitochondrial membrane proteins extracts from both treated and control mice and it was seen that concentration of the protein was significantly higher as shown in Fig II below.

Table l: Total mitochondrial membrane surface protein. $n=10$. ${ }^{\star \star \star \star} p<0.0001$ when control compared with treated

\section{Groups Amount of mitochondrial membrane surface protein $\mathrm{mg} / \mathrm{ml} \pm \mathrm{SEM}, \mathrm{n}=10$}

Control $\quad 2.39 \pm 0.057$

Treated $\quad 4.35 \pm 0.040$

Isolated mitochondrial membrane proteins extract from both treated and control mice were analysed on the SDS- PAGE. Proteins were resolved into several protein bands on a $15 \%$ SDS-PAGE followed by CBB staining of the gel. Differential expression of proteins was observed in the liver mitochondrial membrane of treated mice from those of control Figure III. A protein of approximately $14 \mathrm{kDa}$ was found to be prominently over expressed in treated mice which were also seen in normal mice, as seen clearly from the intensity of the bands in both control and treated mice. In the control mice, the protein was found to be expressed in less intensity as compared to its higher intensity band in the treated mice.

\section{SEPERATION PURIFICATION OF TAA}

\section{ION EXCHANGE CHROMATOGRAPHY}

After identification of the over-expressed protein which was considered as TAA from the treated mice by SDS-PAGE analysis, the extract was subjected to cation exchanger CM-Sephadex C50 for the separation and purification. The elution profile of the cation exchange chromatography is shown in Figure IV. It was seen that most of the proteins eluted out with $50 \mathrm{~mm}$ Phosphate buffer $\mathrm{pH} 7$ in the unbound fraction Figure IV Peak 1, 2. Some minor peaks were also seen in the bound region. The fractions were pooled separately, concentrated and re-resolved on an SDS-PAGE to identify the presence of the desired 3kDa protein.

\section{SDS-PAGE ANALYSIS OF THE PURIFIED PROTEIN}


It was confirmed by SDS-PAGE analysis that the protein of our interest eluted out in the unbound fraction as seen in Figure $V$ and it was anionic in character. The identified $14 \mathrm{kDa}$ protein was found to absent in the bound region i.e. peak 3,4 of the elution profile. A prominent band of approximately $14 \mathrm{kDa}$ was observed in the lane loaded with the fractions of the unbound region.

\section{PREPARATIVE SDS-PAGE FOR PURIFICATION OF THE PROTEIN}

As we didn't obtain a single band from the ion exchange chromatography an additional purification step was carried out. The fractions corresponding to the peaks were pooled together, dialysed against distilled water, concentrated and further purified using preparative SDS-PAGE. The TAA recovered from the preparative SDS-PAGE was subjected to an SDS-PAGE gel and a single band was obtained as shown in Figure Vl.

\section{MOLECULAR WEIGHT DETERMINATION}

The identified and purified protein was then subjected to gel filtration chromatography in order to determine the molecular weight of the purified protein. The molecular weight of the purified protein was determined from the plot of log molecular weight versus Ve/Vo of several calibration standards such as Trypsin, Ribonuclease A, Albumin (bovine serum), and Ovalbumin. The logarithm of their respective molecular weight was plotted against the ratio of their elution volume to void volume. From the calibration curve, the molecular weight of the purified protein was found to be $14.15 \mathrm{kDa}$.

\section{Discussion}

An attempt was also made for proteomic analysis of the liver mitochondrial membrane surface proteins in DEN-treated animals. The SDS-PAGE analysis of liver mitochondrial membrane protein extract showed differential expression of membrane surface proteins in mice upon DBN exposure as compared to that of the normal control (Fig III). Several proteins were found up-regulated or over-expressed upon comparison with the normal. The observed alteration in protein expression clearly indicates that DBN has inflicted major changes in the membrane of mitochondria. These changes could be involved in causing distortions and alterations of the mitochondrial membrane during DBN treatment. On doing SDS-PAGE analysis a protein of approximately $14 \mathrm{kDa}$ was found to be over expressed in the mitochondrial extract from DBN treated mice when compared to that of the extract from control mice. This over expressed protein was also present in the control mice but was found in trace amount as shown in Figure III. We considered this over-expressed as tumor-associated antigen (TAA) because as mentioned above this protein was also present in normal mice but was over-expressed in the case of the DBN treated mice.

After the identification of the TAA an attempt was then made to separate and purify the over-expressed protein which we considered as TAA in DBN treated mice for which ion exchange chromatography, preparative SDS-PAGE, gel filtration methods were employed. On doing the cation exchange chromatography using CM-Sephadex C 50 a cation exchanger it was found that most of the protein had eluted out in the unbound fractions as we can see in the Fig.IV whereas some minor peaks were also seen 
in the bound region. So to confirm whether the protein of interest had eluted out in bound or unbound region SDS-PAGE analysis of both bound and unbound fractions were done. On doing SDS- PAGE analysis the TAA was seen to be eluted out in the unbound fraction. The desired glycoprotein was found to be an anionic protein as evident from the elution profile shown in Fig V.

Further purification of the glycoprotein was carried out by gel filtration chromatography using Sephadex G-75, but could not be achieved due to small differences in the molecular weight of other anionic protein eluted with it. Hence was finally purified by preparative SDS-PAGE. TAA extracted from the preparative SDS-PAGE method was subjected to SDS-PAGE to check its homogeneity and purity. TAA was found to be homogeneous and appeared as a single band (Fig.VI).

The molecular weight of TAA was determined by gel filtration chromatography. Sephadex $\mathrm{G} 75$ column was used for this purpose. The calibration curve was prepared using protein molecular weight markers such as albumin, trypsin, and ribonuclease A. The logarithm of their respective molecular weights (Log $\mathrm{Mr}$ ) was plotted against the ratio of their elution volume to void volume (Ve / Vo). From the calibration curve, the molecular weight of the purified glycoprotein was read and found to be very close to $14.2 \mathrm{kDa}$ (Fig.VII).

\section{Conclusion}

Mitochondrial membrane surface protein of DBN-exposed animals exhibited differential expression when compared with the control animals. A low molecular weight ( $14 \mathrm{kDa})$ protein was found to be over expressed on liver mitochondrial membrane upon DBN exposure in mice as compared with the normal control and identified as TAA, showing the sign that some of the proteins could be used as TAA for further study.

\section{Declarations}

Funding: North Eastern Hill University. Conflicts of interest/Competing interests: None. Availability of data and material: NA.

Code availability: NA

Ethics approval (In case animals were involved): All applicable international, national, and/or institutional guidelines for the care and use of animals were followed, for using swiss albino mice.

Ethics approval (In case humans were involved): NA Consent to participate: NA.

Consent for publication: I, the undersigned, give my consent for the publication of identifiable details, which can include photograph(s) and/or case history and/or details within the text ("Material") to be published in the above Journal and Article. 


\section{References}

1. Matsuhashi T, Yamada N, Shinzawa H, Takahashi T, (June (1996) Effect of alcohol on tumor growth of hepatocellular carcinoma with type C. cirrhosis Int Med 35(6):443-448. doi:10.2169/internalmedicine.35.443. PMID 8835593

2. Bradfield C (2009) Mechanishm of liver carcinogenesis:unit-II-Liver,Metabolism and chemical carcinogenesis.McArdel. Lab.For cancer research,Univ of Wisconsin,Madison

3. Nunnari J, Suomalainen A (2012) Mitochondria: in sickness and in health. Cell 148:1145-1159

4. Minev BR, Chavez FL, Mitchell M (1999) Cancer vaccines:Novel approaches and new promise Pharmacol.Ther.. 81:121.. doi: 10.1016/s0163-7258(98)00039-4

5. Urban JL, Schreiber H (1992) Tumor antigens.Annu. Rev Immunol 10:617. https://doi.org/10.1146/annurev.iy.10.040192.003153

6. Kuby J (1997) Tumor Associated Antigens' in Immunology 3rd Edition,W H Freeman and Company

7. Greten TF, Jaffee EM (1999) Cancer vaccines. J Clin Oncol 17(3):1047-1060. doi: 10.1200/JCO.1999.17.3.1047

8. Laemmeli UK (1970) Clevage of structural proteins during the assembly of the head of bacteriophage T4,Nature, 15;227(5259):680-5. doi: 10.1038/227680a0

9. Bradford MM (1976) A rapid and sensitive for the quantitation of microgram quantities of protein utilizing the principle of protein dye binding. Anal Biochem 1,72:248-254. doi:

10.1006/abio.1976.9999

10. 10. Bradford M.M (1976).A rapid and sensitive for the quantitation of microgram quantities of protein utilizing the principle of protein dye binding.,Analytical Biochemistry 1,72:248-54. doi: 10.1006/abio.1976.9999

\section{Figures}


$\begin{array}{cc}\mathrm{CH}_{3}-\mathrm{CH}_{2}-\mathrm{CH}_{2}-\mathrm{CH}_{2}-\mathrm{N}-\mathrm{CH}_{2}-\mathrm{CH}_{2}-\mathrm{CH}_{2}-\mathrm{CH}_{3} & \text { (Procarcinogen) } \\ \mathrm{N}=\mathrm{O} & \end{array}$

\section{DBN}

$\downarrow$

$\mathrm{CH}_{3}-\mathrm{CH}_{2}-\mathrm{CH}_{2}-\mathrm{CH}_{2}-\mathrm{N}-\mathrm{CH}_{2}-\mathrm{CH}_{2}-\mathrm{CH}_{2}-\mathrm{CH}_{2} \mathrm{OH}$ (Proximate carcinogen) $\mathrm{N}=\mathrm{O}$

HYDROXYBUTYL, BUTYL NITROSAMINE

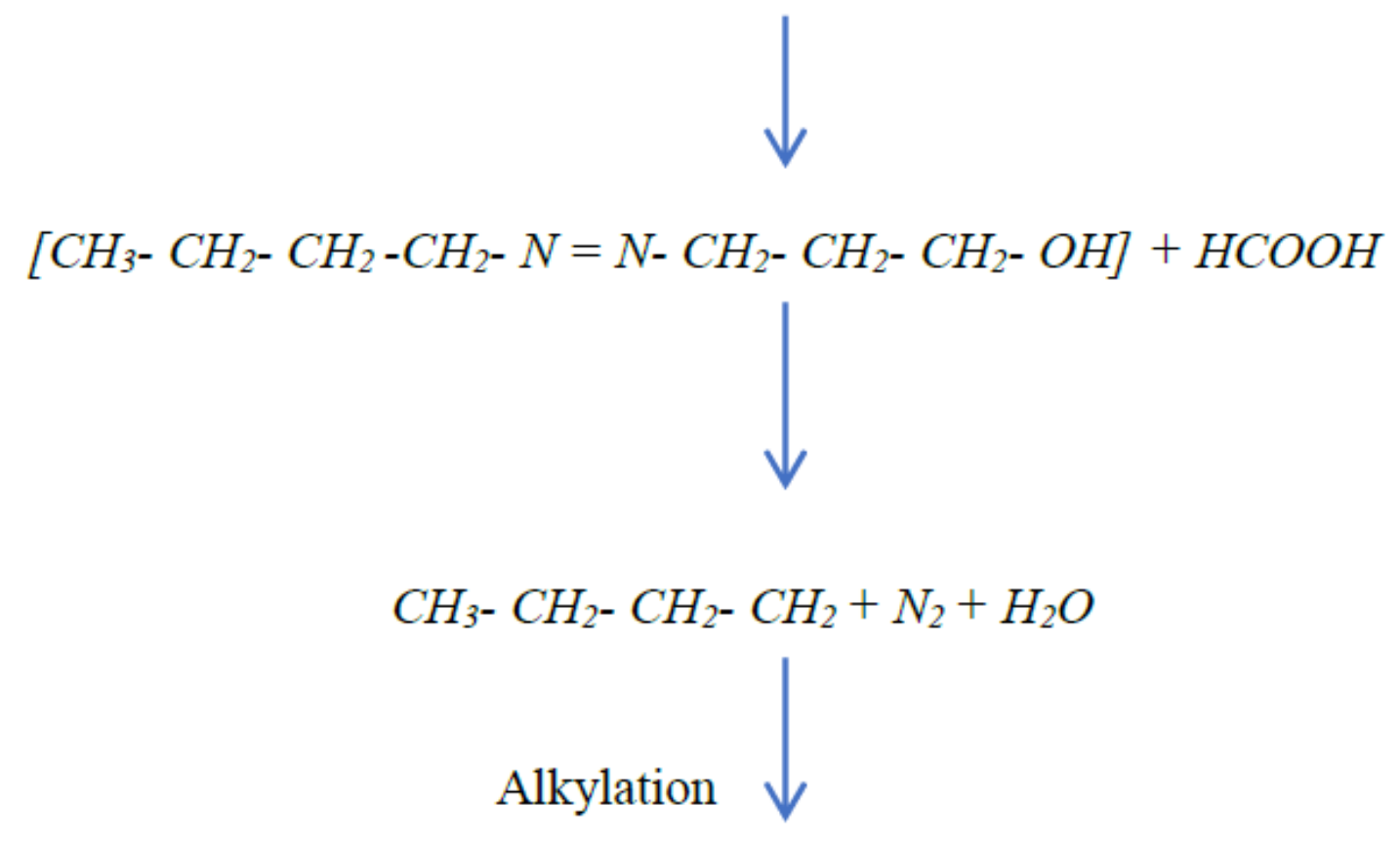

GUANINE

\section{Figure 1}

Proposed metabolic pathways of N, N-dibutylnitosamines (DBN) in case of guanine, where DBN gets metabolic activated by cytochrome p450 enzymes in liver to become ultimate carcinogen, which adds butyl group at $\mathrm{O} 6$ and N7 positions resulting in mutations. 


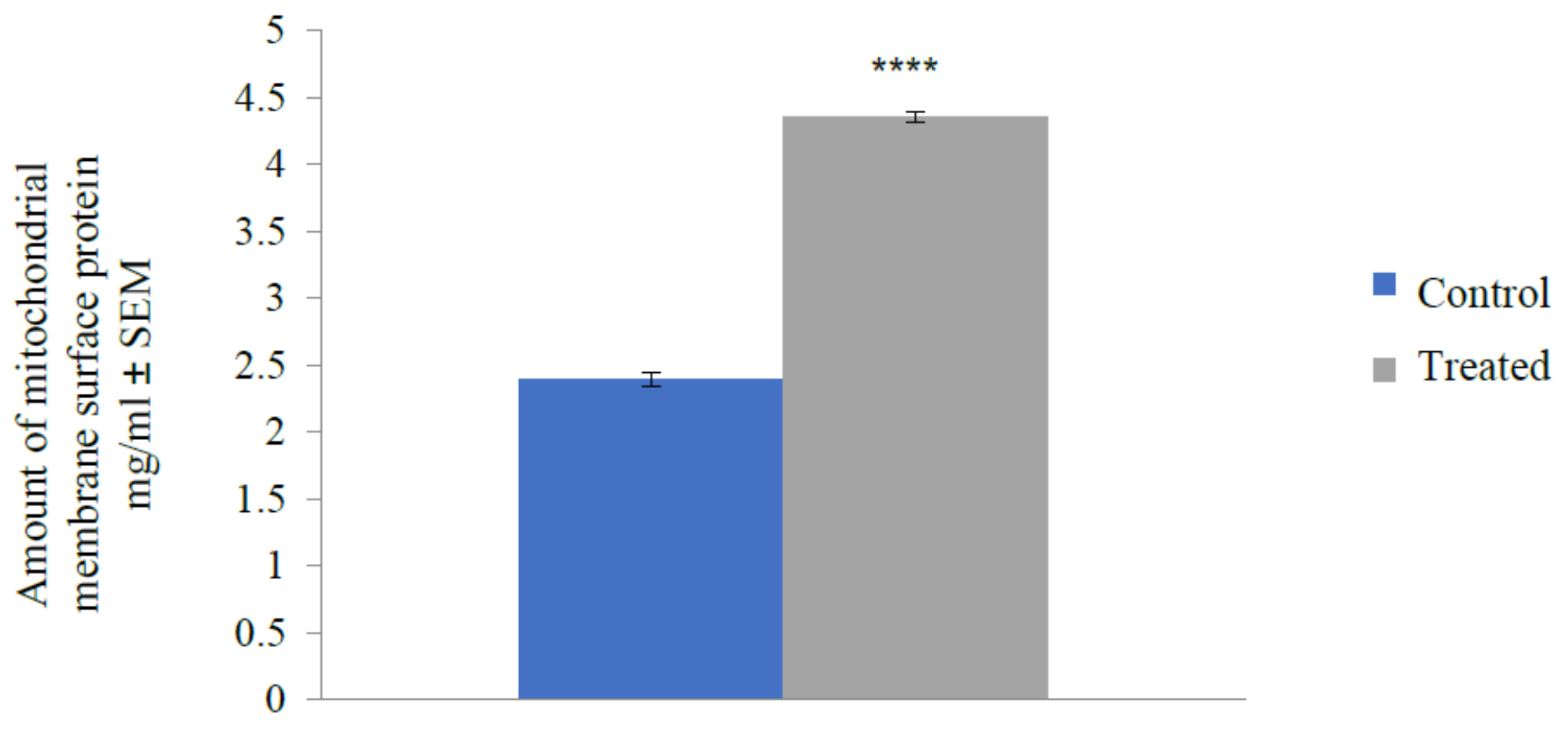

Figure 2

Total mitochondrial membrane surface protein estimation. The values in the bars are expressed as Mean $\pm S E M ; n=10 .{ }^{* \star \star \star} p<0.0001$ when control compared with treated.

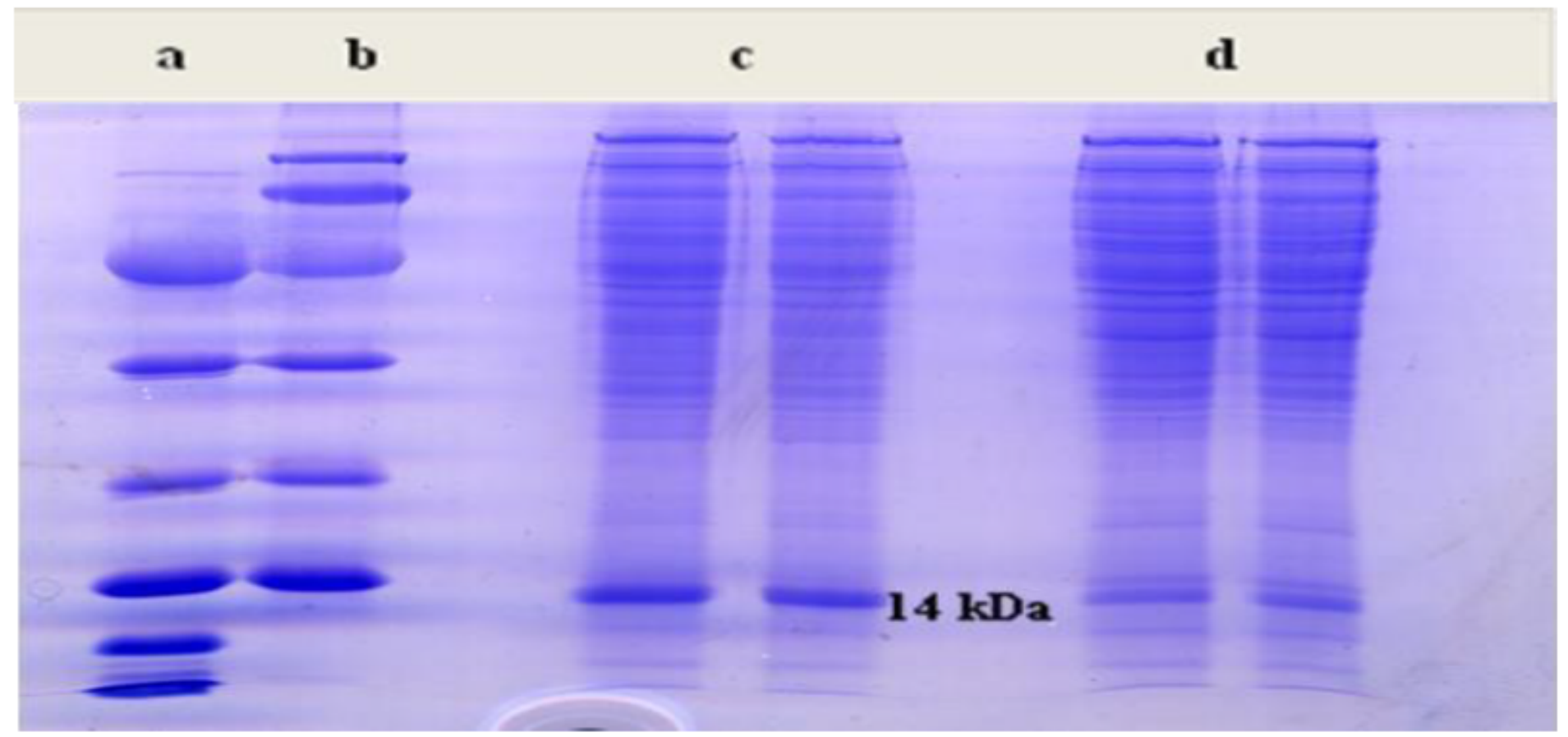

Figure 3

SDS-PAGE analysis of the extracted mitochondrial membrane surface protein obtained from $\mathrm{N}$ Nitrosodibutylamine (DBN) treated mice and normal control mice. Lane (a) Low weight molecular marker, 
Lane (b) Medium weight molecular marker, Lane (c) DBN treated extract and Lane (d) Normal control mice. A protein of approximately $14 \mathrm{kDa}$ was seen to be over expressed in the lane 3 containing DBN treated extract.

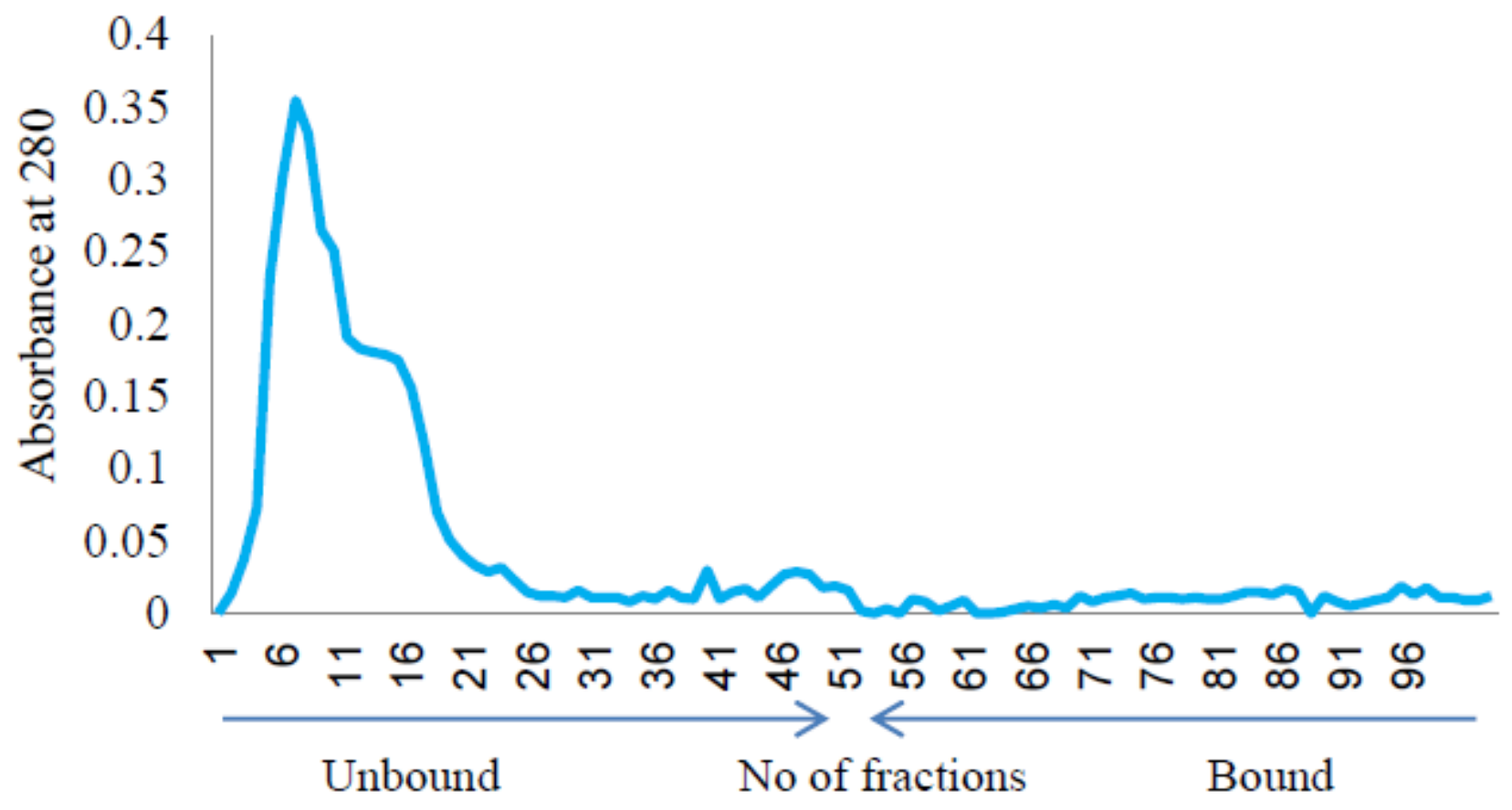

Figure 4

CM-Sephadex $\mathrm{C} 50$ a cation exchange protein profile of the liver mitochondria membrane surface protein from DBN treated mice.

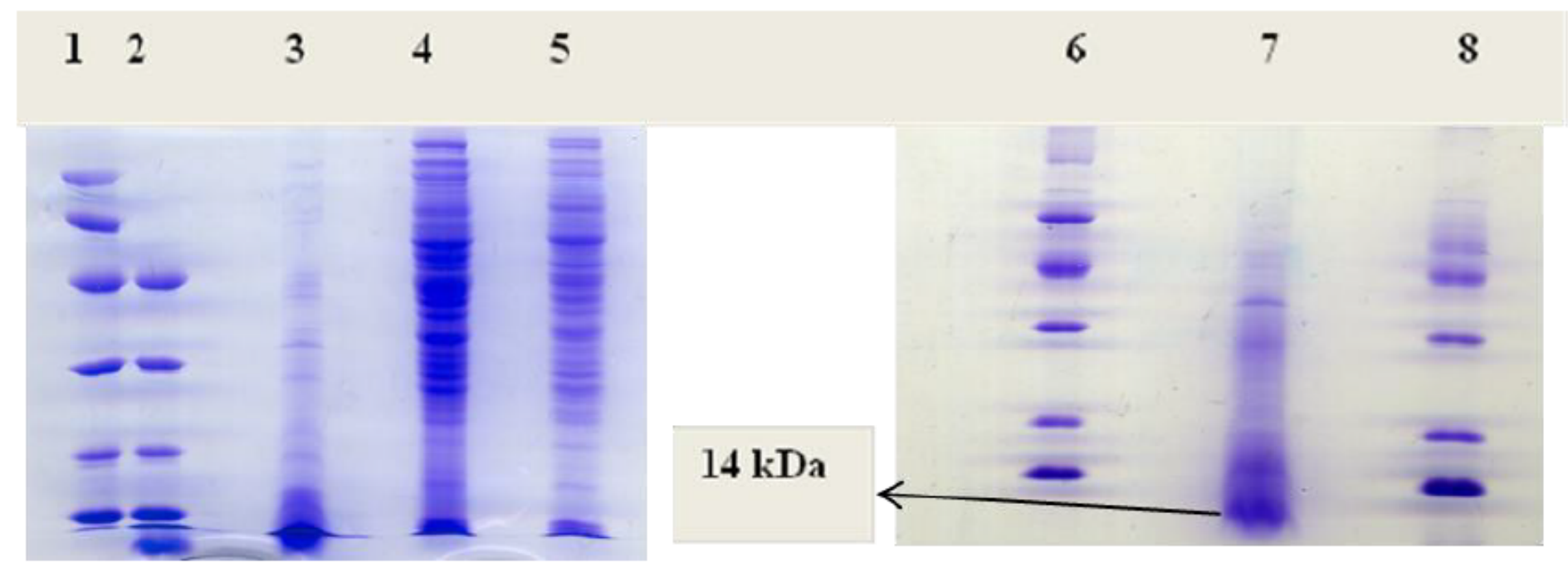

Figure 5 
SDS-PAGE analysis of the unbound fractions obtained from the cation exchange column chromatography of the DBN treated extract. Lane 1 and 6: Medium weight molecular marker, Lane 2 and 8: Low weight molecular marker, Lane 3 and 7: Unbound fractions, Lane 4: DBN treated extract and Lane 5: Control

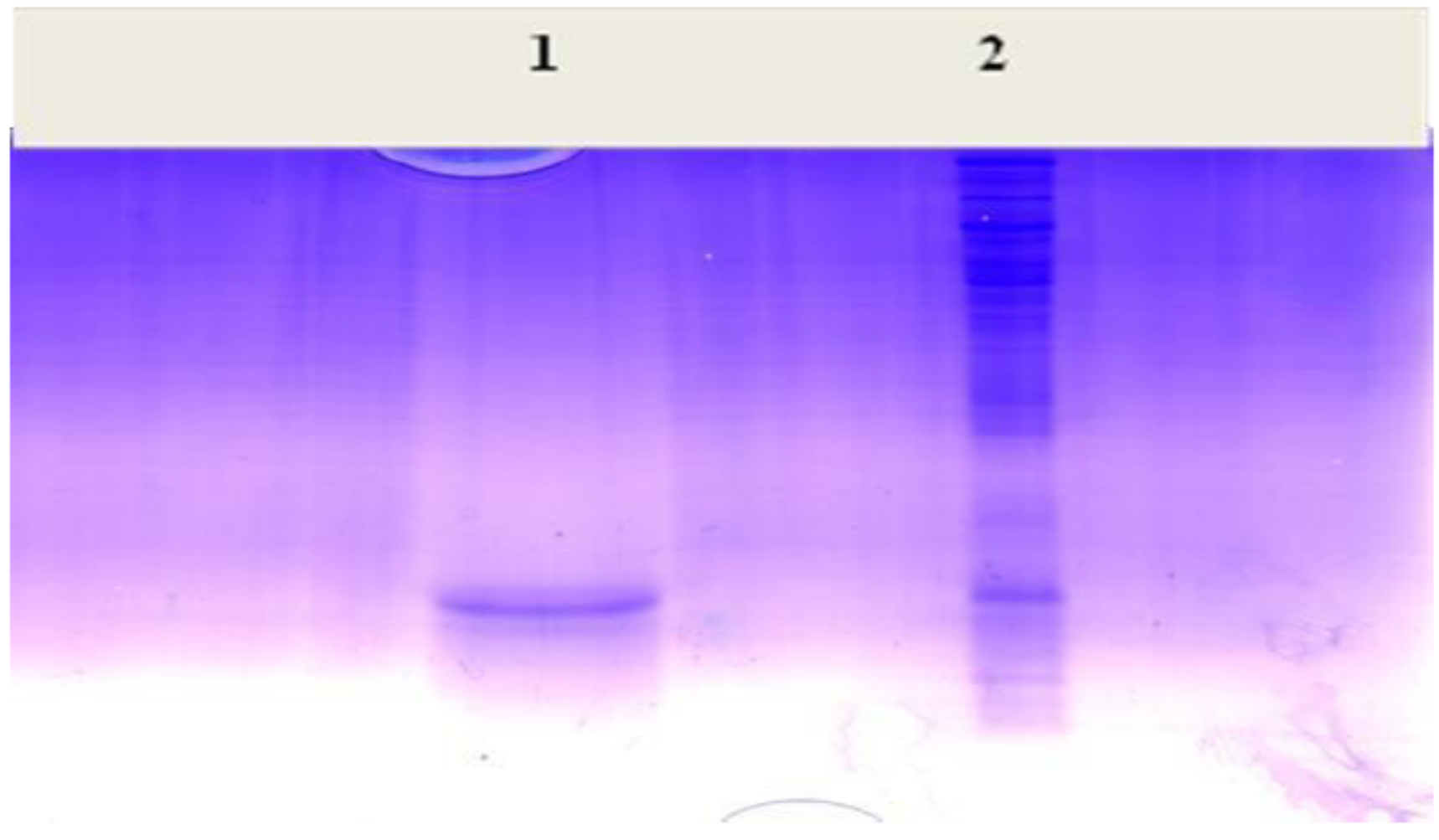

Figure 6

Preparative SDS-PAGE purified TAA. The portion of the gel corresponding to the TAA was cut out of the unstained gel. It was cut into small pieces and homogenized in 3\% 1-butanol. The homogenate was centrifuged at $8000 \mathrm{~g}$ for $30 \mathrm{~min}$ at $4^{\circ} \mathrm{C}$. The supernatant collected was pooled and dialyzed. Lane 1: Purified TAA and Lane 2: DBN treated extract 


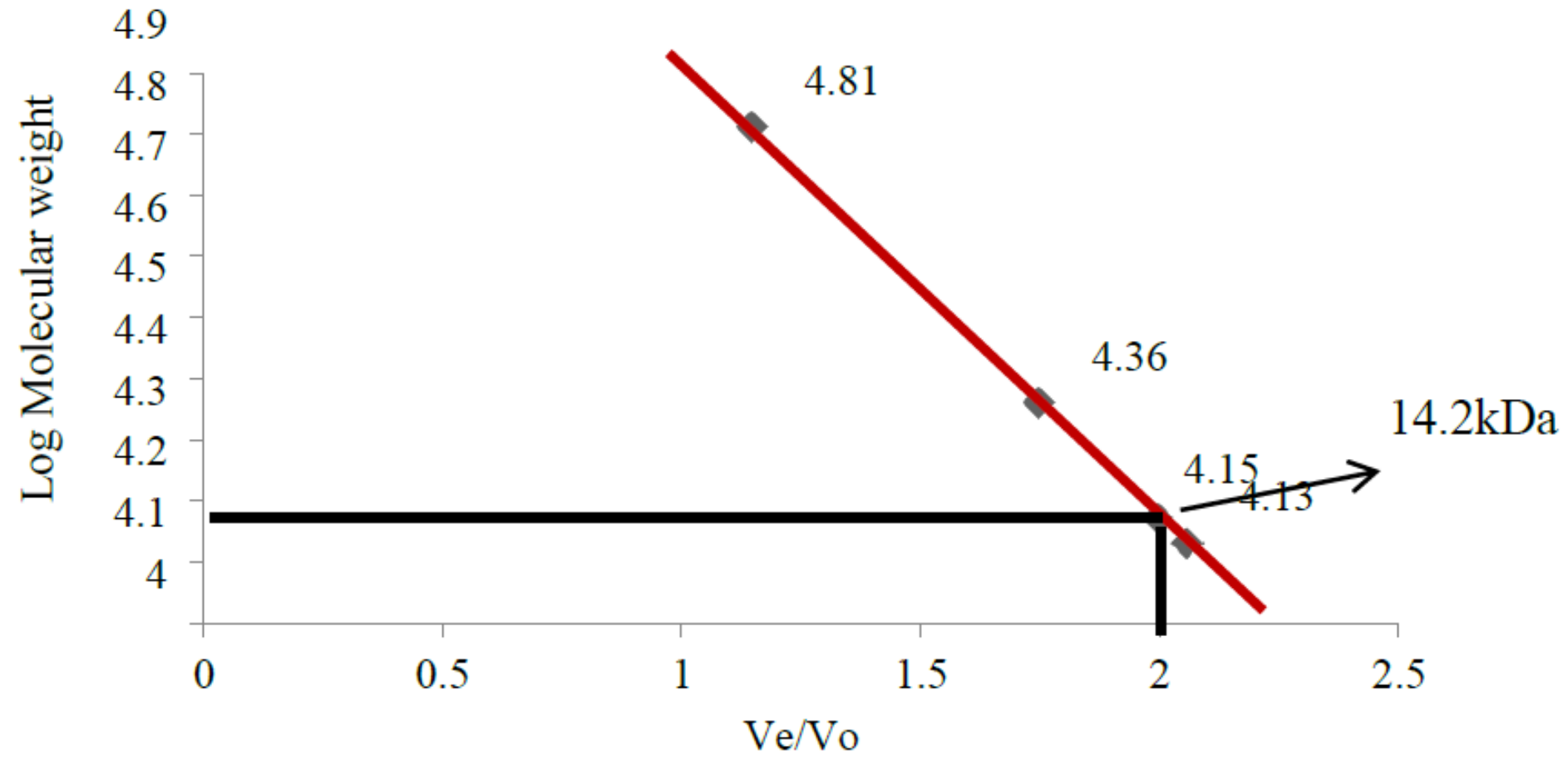

Figure 7

Sephadex G-75 Gel filtration profile showing the molecular weight of the fraction obtained by cationexchange chromatography. 